\title{
A flexibilização da legalidade no Supremo Tribunal Federal: o caso da execução da condenação sujeita a apelos extremos
}

\author{
Flexibility of legality in the Supreme Court's case-law: enforcing \\ criminal sentences pending judgement before high courts
}

\section{Heloisa Estellita ${ }^{1}$}

\author{
Fundação Getúlio Vargas (FGV/DIREITO) - São Paulo/SP \\ heloisa.estellita@fgv.br \\ lattes.cnpq.br/6516595843549222 \\ orcid.org/0000-0002-5054-4116
}

\begin{abstract}
Resumo: O instrumentalismo e a flexibilização das normas jurídicas que reinam, hoje, em nossa cultura jurídica, especialmente em seu componente jurisprudencial, criam desigualdade e insegurança. $\mathrm{O}$ caso da execução da condenação sujeita a apelos extremos retrata os métodos para isso utilizados e comprova que seu produto é a denegação de igualdade e segurança aos jurisdicionados. $\mathrm{O}$ artigo analisa, essencialmente, os argumentos utilizados no julgamento do HC 126.292/STF para evidenciar esse quadro.
\end{abstract}

Palavras-Chave: Execução penal; presunção de inocência; legalidade.

ABSTRACT: The instrumentalism and flexibility of the legal norms that prevail today in our legal culture, especially in its jurisprudential component, create inequality and insecurity. The case of the enforcement of a criminal sentence

1 Agraciada com a Humboldt Research Fellowship para realização de Pós-doutorado na Alemanha, na Ludwig-Maximilians-Universität de Munique e na Universidade de Augsburg (2015-2017), em cooperação com a CAPES. Doutora em Direito Penal pela Universidade de São Paulo (2004). Mestre em Direito (UNESP, 2001). Especialista em Direito Penal Econômico e Europeu (Universidade de Coimbra, 2001). Professora da Escola de Direito da Fundação Getulio Vargas e coordenadora do Grupo de Ensino e Pesquisa em Direito Penal Econômico na mesma instituição. 
pending judgement before high courts depicts the methods for this sake and proves that its outcome is the denial of equality and security. This essay deals with the arguments developed on the adjudication of HC 126.292 by the Brazilian Supreme Court in order to corroborate its findings.

KEYWORDS: service of the sentence; presumption of innocence; legality.

SUMÁRIO: Introdução; 1. Os argumentos vencedores no julgamento do HC 126.292; 2. Crítica; 3. O papel da sorte na vida dos condenados precariamente: insegurança e desigualdade; Conclusão; Referências.

\section{INTRODUÇÃO}

Já se denunciou entre nós o instrumentalismo e a flexibilização das normas jurídicas que reinam, hoje, em nossa cultura jurídica, especialmente em seu componente jurisprudencial, e, dentro dele, a contribuição dada pelo Supremo Tribunal Federal para esse estado de coisas. Enquanto Streck, por exemplo, denunciava que o slogan, segundo o qual não deveríamos mais alimentar um "apego à letra fria da lei", levou a um movimento de "decido de acordo com a minha consciência", 2 Reis criticava a falta de clareza quanto aos critérios utilizados para "superar regras”, que resulta em redução da capacidade dogmática e jurisprudencial de orientar condutas e reduzir incertezas, ${ }^{3}$ redundando, como pretendo demonstrar, em uma aplicação desigual das normas jurídicas.

Os métodos comumente empregados para essa flexibilização das regras jurídicas são (a) a cisão entre regras e princípios e a invocação ilimitada destes, permitindo-se, assim, uma abertura de sentido a ser "preenchida e/ou produzida pelo intérprete", ${ }^{4}$ que culmina em uma in-

2 STRECK, Lenio Luiz. O que é isto - decido conforme a minha consciência? 4. ed. ele. Porto Alegre: Livraria do Advogado, 2013, p. 38.

3 REIS, Thiago. Dogmática e incerteza normativa: crítica ao substancialismo jurídico do direito civil - constitucional. Revista de Direito Civil Contemporâneo, v. 11 , p. 213-238, 2017, p. 217, embora se refira ao direito civil, o fenômeno repete-se no direito penal.

4 STRECK, Lenio Luiz. O que é isto - decido conforme a minha consciência? 4. ed. ele. Porto Alegre: Livraria do Advogado, 2013, p. 58. 
controlável ponderação de interesses e apelo a "razões substanciais" em oposição às "meramente formais", que chegam a ser objeto de desdém; (b) a criação judicial de cláusulas gerais; (c) a confusão entre o ser e o dever-ser atribuindo-se a argumentos de fato o caráter derrogatório de normas jurídicas; e (d) o estabelecimento de distinguishings não contemplados na lei.

O emprego desses métodos resulta em uma "carta branca" aos magistrados, utilizada para esconder o fato de que, com frequência, decidem de acordo com suas convicções pessoais ligadas estritamente ao caso concreto, ${ }^{5}$ o que redunda em uma concepção arriscada do ponto de vista institucional e "incontrolável do ponto de vista dogmático, pois produz todo tipo de incerteza quanto ao direito vigente". ${ }^{6}$

Far-se-á hoje o papel que Leite fez relativamente à invocação da teoria do domínio do fato no julgamento da AP 470, porque se crê, com ele, que "o papel de crítica às decisões judiciais" é uma tarefa primordial da ciência jurídica. ${ }^{7}$ Para isso, será utilizado o caso da admissibilidade do cumprimento da pena sem condenação definitiva tal qual apreciado no

5 Cf. REIS, Thiago. Dogmática e incerteza normativa: crítica ao substancialismo jurídico do direito civil - constitucional. Revista de Direito Civil Contemporâneo, v. 11, p. 213-238, 2017, p. 230; STRECK, Lenio Luiz. O que é isto - decido conforme a minha consciência? 4. ed. ele. Porto Alegre: Livraria do Advogado, 2013, p. 89-90: "Por isso, merecem especial cuidado as decisões que lançam mão especialmente da 'razoabilidade' (com ou sem 'ponderação de valores'), argumentação que se transformou em autêntica 'pedra filosofal da hermenêutica' a partir desse caráter performativo. Excetuando os casos em que, teleologicamente, decisões calcadas na ponderação de valores podem ser consideradas corretas ou adequadas à Constituição (o que por si só já em um problema, porque a interpretação não pode depender dessa 'loteria' de caráter finalístico), a maior parte das sentenças e acórdãos acaba utilizando tais argumentos como um instrumento para o exercício da mais ampla discricionariedade (para dizer o menos) e o livre cometimento de ativismos".

6 REIS, Thiago. Dogmática e incerteza normativa: crítica ao substancialismo jurídico do direito civil - constitucional. Revista de Direito Civil Contemporâneo, v. 11, p. 213-238, 2017, p. 230.

7 LEITE, Alaor. Domínio do fato, domínio da organização e responsabilidade penal por fatos de terceiros. Os conceitos de autor e partícipe na AP 470 do Supremo Tribunal Federal. In: GRECO, Luís [et al.]. Autoria como domínio do fato: estudos introdutórios sobre o concurso de pessoas no direito penal brasileiro. São Paulo: Marcial Pons, 2014, p. 123-168, p. 124. 
julgamento do HC 126.292 pelo Supremo Tribunal Federal (adiante, STF), ${ }^{8}$ utilizando-se as técnicas da pesquisa bibliográfica, documental e de análise de conteúdo, procedendo-se da seguinte forma: serão apresentados os principais argumentos vencedores empregados no julgamento do habeas pelo (STF) para proceder a um giro de cento e oitenta graus relativamente ao entendimento anterior da corte na mesma matéria (abaixo 1), os quais serão, então, submetidos, um a um, a críticas sob os pontos de vista do instrumentalismo e da flexibilização das normas jurídicas (abaixo 2), o que permitirá comprovar que resultam em denegação de segurança e de igualdade aos jurisdicionados (abaixo 3), a evidenciar o papel que a dogmática pode desempenhar para o alcance desse desiderato (conclusão).

\section{Os aRgumentos Vencedores no JUlgamento do HC 126.292}

Até 2016, o acórdão-paradigma era o proferido no julgamento do HC 84.078, de 2009, no qual o plenário do STF decidiu ser inconstitucional a "execução antecipada da pena" por violação ao disposto nos arts. $5^{\circ}$, LVII, e $1^{\circ}$, III, CF. ${ }^{9}$ Em 17 de fevereiro de 2016, porém, o mesmo órgão decidiu, por maioria, que a "execução provisória de acórdão penal condenatório proferido em grau de apelação, ainda que sujeito a recurso especial ou extraordinário, não compromete o princípio constitucional da presunção de inocência afirmado pelo artigo $5^{\circ}$, inciso LVII da Constituição Federal”10. Segundo este dispositivo

8 Até 3 de março de 2018, data de submissão deste texto à RBDPP, este habeas representava o precedente fundamental na matéria e por essa razão são analisados os argumentos utilizados pela Corte naquela ocasião. Devolvido o texto para revisão e complementação, sobreveio o julgamento, pelo Plenário, do HC 152.752, realizado em 22 de março de 2018, no qual a Corte manteve o mesmo entendimento, apesar da mudança de posição do Min. Gilmar Mendes. O acórdão deste último habeas encontra-se pendente de publicação na data desta revisão (18/04/2018), razão pela qual não foi contemplado no texto. Não obstante, a tomar pela notícia divulgada no sítio eletrônico da Corte (http://portal.stf.jus.br/noticias/verNoticiaDetalhe.asp?idConteudo=374437, acesso em 18/04/2018), o novo entendimento do Min. Gilmar Mendes segue a linha já contemplada neste artigo, no item 3, infra.

9 Julgado em 05/02/2009, publicado no DJe 28/02/2010.

10 STF, HC 126.292, Plenário, DJe 17/05/2016. Vencidos os Mins. Rosa Weber, Marco Aurélio, Celso de Mello e Ricardo Lewandowski. 
constitucional "ninguém será considerado culpado até o trânsito em julgado de sentença penal condenatória". ${ }^{11}$

Como se extrai do voto condutor e daqueles que seguiram seu entendimento, os argumentos utilizados demonstram justamente o emprego dos métodos acima apontados para contornar a legalidade democrática em matéria penal. Sintetizo-os:

a) a questão seria a de determinar o alcance de um princípio e, então, proceder à ponderação entre o princípio da presunção de inocência e o da efetividade da função jurisdicional penal, ${ }^{12}$ ou da duração razoável do processo, ${ }^{13}$ tendo em conta que os direitos e garantias individuais não são absolutos, nem ilimitados, devendo-se distinguir princípios de regras, prestigiando-se a credibilidade da justiça; ${ }^{14}$

b) o princípio da presunção de inocência se reduziria a uma regra sobre a distribuição do ônus da prova, válido somente ali onde ainda haja meio recursal que permita reexame de fatos e provas; ${ }^{15}$ ou seja, a partir da segunda instância haveria uma "justificável relativização e até mesmo a própria inversão, para o caso concreto, do princípio da presunção de inocência até então observado"; ${ }^{16}$

c) a autorização legislativa para que a sentença condenatória sujeita a apelos extremos surta efeitos extrapenais justificaria o mesmo tratamento quanto aos efeitos penais, embora a Lei da Ficha Limpa (LC $135 / 2001$ ), art. $1^{\circ}$, I, “consagra como causa de inelegibilidade a existência de sentença condenatória por crimes nela relacionados quando proferidas por órgão colegiado. É dizer, a presunção de inocência não impede que,

11 Sobre seu desenvolvimento no âmbito da proteção de direitos humanos, cf.: SUXBERGER, Antonio H.; AMARAL, Marianne G. A execução provisória da pena e sua compatibilidade com a presunção de inocência como decorrência do sistema acusatório. Revista de Direito Brasileira, v. 16, n. 7, p. 186-210, 2017, p. 191 ss.; também, AMARAL, Augusto J.; CALEFFI, Paulo S. Pré-ocupação de inocência e execução provisória da pena: uma análise crítica da modificação jurisprudencial do STF. Revista Brasileira de Direito Processual Penal, v. 3, n. 3, p. 1073-1114, 2017. p. 1097 ss.

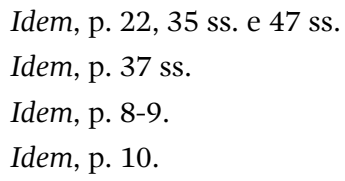


mesmo antes do trânsito em julgado, o acórdão condenatório produza efeitos contra o acusado"; ${ }^{17}$

d) o apego à escolha da linguagem constitucional, que decidiu empregar termo com definição técnica estabilizada ("trânsito em julgado da sentença condenatória"), seria um "apego à literalidade", ${ }^{18}$ fruto de "leitura apressada da literalidade" ${ }^{19}$, expressão de um "formalismo estéril"; ${ }^{20}$

e) uma série de argumentos de fato ou ligados às mazelas do sistema recursal infraconstitucional ou da regulação igualmente infraconstitucional da prescrição, como a de que a "presunção de inocência" "tem permitido e incentivado, em boa medida, a indevida e sucessiva interposição de recursos das mais variadas espécies, com indisfarçados propósitos protelatórios visando, não raro, à configuração da prescrição da pretensão punitiva ou executória"; ${ }^{21}$ ou que os apelos extremos não interrompem a prescrição (art. 117, IV, do CP); ${ }^{22}$ ou o de que o entendimento de 2009 teria servido para "agravar o descrédito do sistema de justiça penal junto à sociedade”, pois conduz à "massiva prescrição”, o que causa "deletéria sensação de impunidade". ${ }^{23}$ Esses argumentos de fato implicariam uma "mutação constitucional", segundo a qual a realidade muda a Constituição, sendo que argumentos pragmáticos permitem ao magistrado uma atuação criativa $;{ }^{24}$ ou mesmo que decida o que seria o "sentimento constitucional". ${ }^{25}$

17 Idem, p. 68.

18 Idem, p. 21, 25.

19 Idem, p. 35.

${ }^{20}$ Idem, p. 46.

${ }^{21}$ Idem, p. 17, 65.

22 Idem, p. 18, 46 ss., 59.

${ }^{23}$ Idem, p. 34.

${ }^{24}$ Idem, p. 35 ss., 49 ss.

25 Idem, p. 60. Há outros argumentos: esse princípio (da presunção de inocência) favorece um indevido "agigantamento os afazeres" do STF (p. 21); a jurisprudência de 2009 incentivou a interposição de recursos, o número de Recursos Extraordinários providos a favor de réus é irrisório $(1,5 \%)$ e as decisões absolutórias não chegam a $0,1 \%$ do total (p. 32-33); só os réus abastados têm condições de recorrer em liberdade e abusar dos meios recursais (p. 33-34); "os mecanismos legais destinados a repelir recursos meramente protelatórios são ainda muito incipientes” (p. 24, 49 ss.). 
Esses os argumentos que me parecem centrais. ${ }^{26}$ Há outros que merecem ao menos um registro. Fez-se um apelo à empatia dos demais magistrados, pois a vedação da execução provisória após o julgamento de segundo grau indicaria uma "presunção absoluta de desconfiança às decisões provenientes das instâncias ordinárias”. ${ }^{27}$ Houve confusão entre prisão processual e cumprimento de pena (no sistema penitenciário) ${ }^{28}$. Ventilou-se um projeto de intervenção político-criminal, pois a "execução provisória de acórdão penal condenatório proferido em grau de apelação pode contribuir para um maior equilíbrio e funcionalidade do sistema de justiça criminal" ${ }^{29}$. Há argumentos conflitantes com a conclusão: "Em suma, a presunção de não culpabilidade é um direito fundamental que impõe o ônus da prova à acusação e impede o tratamento do réu como culpado até o trânsito em julgado da sentença" ${ }^{30}$. Propôs-se a relativização do instituto da coisa julgada, já que recursos extremos não teriam vocação para fazer justiça no caso concreto, daí sua excepcionalidade; ${ }^{31}$ por isso é que haveria uma "coisa julgada singular" derivada do fato de que nos apelos excepcionais não se discutiria mais prova, havendo, assim,

26 Alguns desses argumentos encontram eco, por exemplo, em: SUXBERGER, Antonio H.; AMARAL, Marianne G. A execução provisória da pena e sua compatibilidade com a presunção de inocência como decorrência do sistema acusatório. Revista de Direito Brasileira, v. 16, n. 7, p. 186-210, 2017, passim.

STF, HC 126.292, p. 25: "Se afirmamos que a presunção de inocência não cede nem mesmo depois de um Juízo monocrático ter afirmado a culpa de um acusado, com a subsequente confirmação por parte de experientes julgadores de segundo grau, soberanos na avaliação dos fatos e integrantes de instância à qual não se opõem limites à devolutividade recursal, reflexamente estaríamos a afirmar que a Constituição erigiu uma presunção absoluta de desconfiança às decisões provenientes das instâncias ordinárias".

28 Idem, p. 37. Novamente na p. 39: "Não há dúvida de que a presunção de inocência ou de não-culpabilidade é um princípio, e não uma regra. Tanto é assim que se admite a prisão cautelar (CPP, art. 312) e outras formas de prisão antes do trânsito em julgado. Enquanto princípio, tal presunção pode ser restringida por outras normas de estatura constitucional (desde que não se atinja o seu núcleo essencial), sendo necessário ponderá-la com os outros objetivos e interesses em jogo". Também p. 67.

Idem, p. 23. 
uma parcial "imutabilidade" própria do trânsito em julgado ${ }^{32}$. Por fim, referiu-se que outros sistemas jurídicos não suspendem a execução da pena após o esgotamento do duplo grau de jurisdição. ${ }^{33}$

A crítica aos argumentos centrais do novo entendimento evidenciará por qual razão é este um “caso” paradigmático das referidas flexibilização e instrumentalização das normas jurídicas.

\section{CRítICA}

A leitura do acórdão frustra aquele que ali busca a esperada discussão acerca do sentido literal possível da expressão "trânsito em julgado da sentença condenatória”, escolhida por nada menos que o Constituinte. As referências feitas a esse ato processual, ao contrário do que seria de se esperar, não buscam discutir seu possível sentido jurídico, mas propor sua relativização com base em juízos de ponderação com outros princípios constitucionais, tachando de "formalismo estéril" o respeito ao sentido possível de expressão que pertence à linguagem técnica do Direito, estável em nossa tradição jurídica e que foi selecionada pelo poder de maior hierarquia democrática, a Assembleia Constituinte. ${ }^{34}$ Parafraseando Ávila, o

32 Idem, p. 59, o qual tem o mérito de, ao menos, de registrar conhecimento acerca do sentido técnico da expressão trânsito em julgado da sentença condenatória.

33 Idem, p. 12, 69. O enfrentamento desse argumento em AMARAL, Augusto J.; CALEFFI, Paulo S. Pré-ocupação de inocência e execução provisória da pena: uma análise crítica da modificação jurisprudencial do STF. Revista Brasileira de Direito Processual Penal, v. 3, n. 3, p. 1073-1114, 2017, p. 1085 ss.; chama atenção a divergência entre o que consta do voto e a disciplina portuguesa (cf. p. 1086).

34 Trata-se aqui de uma condição de comunicação entre constituinte e aplicador da lei, cuja traição pode criar um "descompasso entre a previsão constitucional e o direito constitucional concretizado" (ÁVILA, Humberto. Teoria dos princípios: da definição à aplicação dos princípios jurídicos. 5. ed. São Paulo: Malheiros, 2006, p. 33-34). Assim, "Compreender 'provisória' como permanente, 'trinta dias' como mais de trinta dias, 'todos os recursos' como alguns recursos, 'ampla defesa' como restrita defesa, 'manifestação concreta de capacidade econômica' como manifestação provável de capacidade econômica, não é concretizar o texto constitucional. É, a pretexto de concretizá-lo, menosprezar seu sentido mínimo" (idem, p. 34). Sobre o limite semântico e seu papel fundamental na democracia, cf. STRECK, Lenio Luiz. Os limites semânticos e sua importância na e para a democracia. Revista da AJURIS, v. 41, n. 135, p. 173-187, 2014, passim. 
STF não pode compreender o "até o trânsito em julgado de sentença penal condenatória” como até o julgamento da apelação, ou, como pretendem alguns magistrados (cf. infra), até o julgamento do recurso especial. É verdade que o Constituinte usou a expressão, mas não a conceituou. Também é verdade que essa conceituação está hoje lançada em instrumento legislativo infraconstitucional ${ }^{35}$. Considere-se, porém, que se trata de expressão que tem sentido técnico anterior à Constituição, ${ }^{36} \mathrm{o}$ que permitiria pensar que o constituinte a empregou precisamente nesse sentido, o qual, ademais, permanece inalterado até o presente momento. ${ }^{37}$

Por outro lado, parece que o enunciado do art. $5^{\circ}$, LVII, CF, contém uma regra. Como afirmou o Min. Sepúlveda Pertence, ele parece veicular uma "regra constitucional de que ninguém será considerado culpado antes que transite em julgado a condenação", ${ }^{38}$ e não (apenas) um mandado de promoção gradual; ${ }^{39}$ ao menos não no que diz respeito ao termo inicial

35 Lei de Introdução às normas do Direito Brasileiro (antiga LICC), art. $6^{\circ}$, § $3^{\circ}$. Cf. SUXBERGER, Antonio H.; AMARAL, Marianne G. A execução provisória da pena e sua compatibilidade com a presunção de inocência como decorrência do sistema acusatório. Revista de Direito Brasileira, v. 16, n. 7, p. 186-210, 2017, p. 195; também BADARÓ, Gustavo Henrique; LOPES JÚNIOR, Aury. Presunção de inocência: do conceito de trânsito em julgado da sentença penal condenatória. 2016. Disponível em: <emporiododireito.com.br/wp-content/ uploads/2016/06/Parecer_Presuncao_de_Inocencia_Do_concei.pdf> Acesso em: 20 fev. 2018, p. 17-18.

36 O dado pela LICC, que é de 1942, e foi mantido mesmo com a reforma que passou a denomina-la Lei de Introdução às normas do Direito Brasileiro, que é de 1942.

37 A alteração da Lei de Introdução às normas do Direito Brasileiro pela Lei 12.376/2010 manteve intacta a definição.

38 STF, HC 69964, DJ 01/07/1993, fl. 275.

39 "As regras podem ser dissociadas dos princípios quanto ao modo como prescrevem o comportamento. As regras são normas imediatamente descritivas, na medida em que estabelecem obrigações, permissões e proibições mediante a descrição da conduta a ser cumprida. Os princípios são normas imediatamente finalísticas, já que estabelecem um estado de coisas cuja promoção gradual depende dos efeitos decorrentes da adoção de comportamentos a ela necessários. Os princípios são normas cuja qualidade frontal é, justamente, a determinação da realização de um fim juridicamente relevante, ao posso que característica dianteira das regras é a previsão do comportamento" (ÁVILA, Humberto. Teoria dos princípios: da definição à aplicação dos princípios jurídicos. 5. ed. São Paulo: Malheiros, 2006, p. 167-168). 
de incidência das consequências penais da norma incriminadora, ou seja, a execução da pena. ${ }^{40}$ Regras "expressam deveres definitivos e são aplicadas por meio de subsunção”, não dependem de sopesamento entre princípios colidentes para serem aplicadas, uma característica justamente dos princípios. ${ }^{41}$ No caso da regra constitucional que examinamos, trata-se de saber se, no caso concreto, há, ou não, uma sentença condenatória transitada em julgado, que é o marco a partir do qual uma pessoa pode ser considerada culpada e com isso ser recipiente de todas as consequências daí advindas, sendo a mais grave dentre elas a direta restrição à liberdade de locomoção e/ou ao patrimônio. A norma não determina ao legislador e ao juiz que, até o trânsito em julgado da sentença condenatória, tratem o cidadão, na maior medida possível,,$^{42}$ como "não-culpado" ${ }^{43}$; ela veicula o dever definitivo de não tratamento como culpado de quem não foi condenado "com trânsito em julgado”, exige, pois, um juízo de subsunção, e não de sopesamento entre princípios colidentes". ${ }^{44}$

Não se deve perder de vista, porém, a advertência de Silva, no sentido de que a prática jurídica brasileira consagrou o emprego de expressões como "princípio da legalidade" ou "princípio da presunção de

40 Esta afirmação não se incompatibiliza com o entendimento que saca desse mesmo dispositivo (art. 5 , LVII, CF) uma norma-princípio (da presunção de inocência, cf., por todos, MORAES, Maurício Zanóide de. Presunção de inocência no processo penal brasileiro: análise de sua estrutura normativa para a elaboração legislativa e para a decisão judicial. Rio de Janeiro: Lumen Juris, 2010, especialmente p. 270-274), pois a partir de um mesmo dispositivo podem ser construídas diversas normas, sejam regras, sejam princípios (cf. ÁVILA, Humberto. Teoria dos princípios: da definição à aplicação dos princípios jurídicos. 5. ed. São Paulo: Malheiros, 2006, p. 30).

41 SILVA, O proporcional e o razoável, p. 25; ALEXY, Robert. Teoria de los derechos fundamentales. Madrid: Centro de Estudios Políticos y Constitucionales, 2001, p. 86-90.

SILVA, Virgílio Afonso da. O proporcional e o razoável. Revista dos Tribunais, v. 798, p. 23-50, 2002, p. 25.

43 Uso a expressão para deliberadamente evitar a discussão acerca de se esta norma teria veiculado um "princípio" de inocência ou de "não culpabilidade", o que, no contexto deste artigo, é secundário.

44 SILVA, Virgílio Afonso da. O proporcional e o razoável. Revista dos Tribunais, v. 798, p. 23-50, 2002, p. 25; também: ALEXY, Robert. Teoria de los derechos fundamentales. Madrid: Centro de Estudios Políticos y Constitucionales, 2001, p. 87. 
inocência”, atribuindo-lhes forte carga semântica, sendo ingênuo crer que se possa, a esta altura, uniformizar a terminologia. ${ }^{45} \mathrm{O}$ que é preciso ter claro é que quando se fala em "princípios" nestes casos, não se está a utilizar a expressão no sentido da teoria de Alexy, ou seja, como contrapostos a regras, mas, aparentemente, no sentido de que os princípios teriam uma maior importância frente às regras, ${ }^{46} \mathrm{com}$ o que nada se diz sobre suas estrutura e forma de aplicação. ${ }^{47}$ Mas mesmo que se tratasse de um princípio, não caberia ao tribunal fazer juízo de ponderação com prevalência do "interesse público" quando, para parafrasear novamente o Min. Sepúlveda Pertence, "foi a Constituição mesma que ponderou os valores contrapostos e optou - em prejuízo, se necessário da eficácia da persecução criminal -" 48 pela liberdade enquanto não houver juízo definitivo sobre todos os pressupostos de aplicação da pena criminal. Se juízo de ponderação houve, ele foi feito em momento anterior, pelo Constituinte, quem decidiu não deixar, nem ao legislador, tampouco ao aplicador da lei, margem para outras ponderações.

Por outro lado, certos argumentos utilizados no julgamento pretendem derivar consequências normativas constitucionais de fatos históricos contingenciais, ${ }^{49}$ com o que confundem a dimensão do ser e do

45 SILVA, Virgílio Afonso da. O proporcional e o razoável. Revista dos Tribunais, v. 798, p. 23-50, 2002, p. 26.

46 Critério esse não utilizado por Alexy (cf. ALEXY, Robert. Teoria de los derechos fundamentales. Madrid: Centro de Estudios Políticos y Constitucionales, 2001, p. 84).

47 SILVA, Virgílio Afonso da. O proporcional e o razoável. Revista dos Tribunais, v. 798, p. 23-50, 2002, p. 25. Exemplifica ele com o emprego da expressão "princípio da proporcionalidade" (idem, p. 25-26), cujas máximas parciais (adequação, necessidade e proporcionalidade em sentido estrito) são catalogadas como regras por Alexy (ALEXY, Robert. Teoria de los derechos fundamentales. Madrid: Centro de Estudios Políticos y Constitucionales, 2001, p. 112, nota. 84). STF, HC 79512, DJ 16/05/2003.

REIS, Thiago. Dogmática e incerteza normativa: crítica ao substancialismo jurídico do direito civil - constitucional. Revista de Direito Civil Contemporâneo, v. 11, p. 213-238, 2017, p. 220. Um desses argumentos de fato é retomado em recente artigo, no qual se conecta a vedação da execução provisória da pena à "continuidade dos esquemas de corrupção", um argumento que adquire um tom quase apelativo em tempos de Lava-Jato. No mesmo texto, sugere-se que é a demora na conclusão de processos (em virtude da vedação de execução provisória) que gera a indesejada "impunidade", o que leva à 
dever-ser, ${ }^{50}$ transformam uma "proibição categórica" em uma "recomendação contingente", ${ }^{11}$ além de propor uma interpretação da Constituição a partir de uma parte selecionada legislação infraconstitucional, com o que não só subverte a hierarquia das fontes normativas, como deixa de fundamentar por qual razão apenas uma parte dessa legislação foi selecionada para irradiar seus efeitos sobre a interpretação e outra não. $\mathrm{O}$ mesmo argumento poderia ser usado contra o próprio proceder, pois o instituto do trânsito em julgado da sentença é regulado justamente por lei infraconstitucional. ${ }^{2}$

conclusão de que somente com o abandono da determinação constitucional poderemos alcançar a efetividade punitiva e, pois, reduzir os patamares de corrupção (BARROSO, Luís Roberto; SCHIETTI, Rogério. Execução penal, opinião e fatos. Folha de São Paulo, 02/02/2018. Disponível em: <https:// www1.folha.uol.com.br/opiniao/2018/02/luis-roberto-barroso-e-rogerio-schietti-execucao-penal-opiniao-e-fatos.shtml>. Acesso em: 20 fev. 2018). Deixando de lado o argumento empírico, o argumento de conveniência possibilitaria a admissibilidade da tortura para a obtenção de provas eficazes em casos de crimes graves (cf., por todos, GRECO, Luís. Conveniência e respeito. Sobre o hipotético e o categórico na fundamentação do Direito Penal. Revista Brasileira de Ciências Criminais, v. 95, p. 43-83, 2012, p. 51-54; cf. adiante item 4), e, por que não, a limitação do uso do habeas corpus sem a necessidade da decretação de estado de sítio ou estado de defesa (cf. AMARAL, Thiago Bottino do. Habeas corpus nos Tribunais Superiores: uma análise e proposta de reflexão. Rio de Janeiro: Escola de Direito do Rio de Janeiro da Fundação Getúlio Vargas, 2016, p. 100-101).

Cf. NEUMANN, Ulfrid. Bedingungen der Validität des naturalistischen Fehlschlusses. In: Festschrift für Matthias Mahlmann. Baden-Baden: Nomos, 2011, p. $62-70$.

51 Cf. GRECO, Luís. Conveniência e respeito. Sobre o hipotético e o categórico na fundamentação do Direito Penal. Revista Brasileira de Ciências Criminais, v. 95, p. 43-83, 2012, passim.

52 Refiro-me ao conjunto de normas federais que cuidam da execução penal, como já tinham notado CARVALHO, Salo de; WUNDERLICH, Alexandre. Crítica à execução antecipada da pena: a revisão da Súmula 367 pelo STJ. In: Crítica à execução penal. 2. ed. Rio de Janeiro: Lumen Juris, 2007, p. 447-462, p. 451; e, AMARAL, Augusto J.; CALEFFI, Paulo S. Pré-ocupação de inocência e execução provisória da pena: uma análise crítica da modificação jurisprudencial do STF. Revista Brasileira de Direito Processual Penal, v. 3, n. 3, p. 1073-1114, 2017, p. 1094; SUXBERGER, Antonio H.; AMARAL, Marianne G. A execução provisória da pena e sua compatibilidade com a presunção de inocência como decorrência do sistema acusatório. Revista de Direito Brasileira, v. 16, n. 7, p. 186-210, 2017, p. 187. 
O entendimento evidencia, ainda, um intento de transferir aos magistrados atribuições exclusivas do legislador, pois ao pretender resolver, com a negativa de vigência de uma norma constitucional, problemas legislativos localizados em nível infraconstitucional (prescrição e sistema recursal penal), usurpa competência constitucionalmente atribuída ao Congresso Nacional (art. 22, I, CF). Tampouco os problemas pertinentes à administração dos órgãos encarregados da persecução e execução penais (duração razoável do processo e impunidade) ${ }^{53}$ podem ser resolvidos no caso concreto, às custas do corpo de um cidadão, mas devem ser resolvidos em esferas próprias seja da administração do Poder Judiciário, seja do Poder Executivo. ${ }^{54}$

Por fim, a posição assumida parece ignorar que o pressuposto sine qua non da aplicação da pena é a afirmação da culpa (em sentido lato) de um sujeito concreto acusado por um crime concreto. A afirmação dessa culpa só pode se dar por meio das regras do devido processo legal. Com outras palavras, a afirmação da culpa (em sentido lato) é uma conclusão acerca da tipicidade, ilicitude e de culpabilidade daquele concreto acusado, alcançada por meio de um devido processo legal, no âmbito do qual se tenha obtido a comprovação empírica de todos os pressupostos da pena. Disso deriva que a discussão sobre qualquer um desses pressupostos impede uma afirmação definitiva de culpa daquele acusado por aquele fato concreto. Daí que a exigência constitucional de definitividade do juízo de culpa para a aplicação da pena só possa se dar quando não estejam sendo mais discutidos esses pressupostos, o que

53 Em sentido similar: AMARAL, Augusto J.; CALEFFI, Paulo S. Pré-ocupação de inocência e execução provisória da pena: uma análise crítica da modificação jurisprudencial do STF. Revista Brasileira de Direito Processual Penal, v. 3, n. 3, p. 1073-1114, 2017, p. 1090; e BADARÓ, Gustavo Henrique; LOPES JÚNIOR, Aury. Presunção de inocência: do conceito de trânsito em julgado da sentença penal condenatória. 2016. Disponível em: <emporiododireito.com. br/wp-content/uploads/2016/06/Parecer_Presuncao_de_Inocencia_Do_ concei.pdf> Acesso em: 20 fev. 2018, p. 36 ss.

54 Cf. os contra-argumentos empíricos alinhavados por QUEIROZ, Rafael M. R. A presunção de inocência libertada. Jota, 2018. Disponível em: <https:// www.jota.info/opiniao-e-analise/artigos/presuncao-de-inocencia-libertada-28022018>. Acesso em 28 mar. 2018. 
independe de o recurso admitir ou não a discussão de fatos ou provas, ${ }^{55}$ e de ter ou não efeito suspensivo. ${ }^{56}$

\section{O PAPEL DA SORTE NA VIDA DOS CONDENADOS PRECARIAMENTE: INSEGURANÇA E DESIGUALDADE}

Muito tempo não foi necessário para que começassem a ser concedidas medidas liminares em sentido contrário ao entendimento fixado por maioria no Plenário. Ministros vencidos naquele julgamento passaram a conceder liminares (cf., por exemplo, HCs 144.712-MC; 145.380-MC; 146.006-MC; 146.185-MC; 148.891-MC). As causas para um tal fenômeno são diversas, mas não seria de todo inapropriado cogitar que essa forma de proceder também seja uma consequência dos defeitos argumentativos do entendimento majoritário acima denunciados.

Levantamento feito no sítio do tribunal no começo de dezembro de 2017, levando em conta também decisões monocráticas, demonstrou que havia 5 Ministros que não admitiam a execução provisória e 6 que a admitiam. ${ }^{57}$ Sendo que, pela composição da Corte, é possível que, no âmbito da Segunda Turma, seja formada maioria no sentido da inadmissão

55 Cf. STF, HC 126.292, p. 45-46. Por isso, discorda-se parcialmente do entendimento de: SUXBERGER, Antonio H.; AMARAL, Marianne G. A execução provisória da pena e sua compatibilidade com a presunção de inocência como decorrência do sistema acusatório. Revista de Direito Brasileira, v. 16, n. 7, p. 186-210, 2017, p. 196. Convergente e agregando outros argumentos, BADARÓ, Gustavo Henrique; LOPES JÚNIOR, Aury. Presunção de inocência: do conceito de trânsito em julgado da sentença penal condenatória. 2016. Disponível em: <emporiododireito.com.br/wp-content/uploads/2016/06/Parecer_Presuncao_de_Inocencia_Do_concei.pdf> Acesso em: 20 fev. 2018, p. 20 ss.

56 Cf., ilustrativamente, LOPES JÚNIOR, Aury. Direito processual penal. 10. ed. São Paulo: Saraiva, 2013, p. 1305-1310; BADARÓ, Gustavo Henrique. Processo penal. 3. ed. São Paulo: Revista dos Tribunais, 2015, p. 891; e, juntos, em: BADARÓ, Gustavo Henrique; LOPES JÚNIOR, Aury. Presunção de inocência: do conceito de trânsito em julgado da sentença penal condenatória. 2016. Disponível em: <emporiododireito.com.br/wp-content/uploads/2016/06/Parecer_Presuncao_de_Inocencia_Do_concei.pdf> Acesso em: 20 fev. 2018, p. 28 ss.

57 Admitem execução provisória: Fachin ( $\left.2^{\mathrm{a}} \mathrm{T}\right)$; Tóffoli $\left(2^{\mathrm{a}} \mathrm{T}\right)$; Barroso $\left(1^{\mathrm{a}} \mathrm{T}\right)$; Fux ( $\left.1^{\mathrm{a}} \mathrm{T}\right)$; Moraes ( $\left.1^{\mathrm{a}} \mathrm{T}\right)$; Cármen Lúcia (Pres.). Não a admitem Mendes $\left(2^{\mathrm{a}}\right.$ T.); Lewandowski ( $2^{\mathrm{a}}$ T.); Celso de Mello ( $2^{\mathrm{a}}$ T. $)$; Rosa Weber ( $1^{\mathrm{a}}$ T.) e Marco Aurélio ( $1^{\mathrm{a}}$ T.). 
da execução provisória, pois três de seus membros estão entre os que têm concedido liminares.

Trocando em miúdos: a prisão para cumprir pena mesmo com condenação ainda precária depende, atualmente, do sistema de distribuição automática do STF, ou seja, de um algoritmo, com o que o STF nega aos jurisdicionados tanto a igualdade como a segurança jurídicas.

Mesmo no caso da revisão de entendimento por um dos magistrados, não se anuncia melhoria nesse estado de coisas, porque os fundamentos da mudança de entendimento assentam-se, novamente, na utilização de mecanismos que criam uma possível esfera de reserva para a justiça do caso concreto.

Isto porque o magistrado que reviu parcialmente sua posição anterior, ${ }^{58}$ passou a entender, juntamente com outro magistrado da Corte, ${ }^{59}$ que a execução provisória da pena somente é admissível (a) quando pendente única e exclusivamente o julgamento de recurso extraordinário, porque dificultado o acesso a essa via recursal em razão da exigência de repercussão geral; (b) não obstante, mesmo neste caso, seria admissível a execução, mesmo na pendência de julgamento de recurso especial, se o crime for "grave", já que, neste caso, é a "própria credibilidade das instituições em geral, e da justiça em particular, [que] fica abalada se o condenado por crime grave não é chamado a cumprir sua pena em tempo razoável", do que decorre que "a garantia da ordem pública autoriza a prisão, em casos graves, após o esgotamento das vias ordinárias”. ${ }^{60}$

58 Trata-se do Min. Gilmar Mendes e a primeira manifestação nesse sentido, embora sem efeitos práticos no caso concreto, parece ter sido feita no julgamento do HC 142.173, DJe 06/06/2017.

59 O Min. Dias Tóffoli: "No julgamento do HC 126.292/SP, o Ministro Dias Tóffoli votou no sentido de que a execução da pena deveria ficar suspensa com a pendência de recurso especial ao STJ, mas não de recurso extraordinário ao STF. Para fundamentar sua posição, sustentou que a instituição do requisito de repercussão geral dificultou a admissão do recurso extraordinário em matéria penal, que tende a tratar de tema de natureza individual e não de natureza geral - ao contrário do recurso especial, que abrange situações mais comuns de conflito de entendimento entre tribunais" (HC 142.173, DJe 06/06/2017, voto do relator Min. Gilmar Mendes, p. 5).

60 HC 149.366, Min. Gilmar Mendes, decisão monocrática denegando a ordem, DJe 24/11/2017: "Entretanto, tenho que o entendimento não deve ser aplicado indistintamente, sobretudo quando tratar-se de condenação por 
No primeiro caso, invoca-se (novamente) um argumento meramente contingencial para estabelecer a distinção de tratamento: o fato de um dos recursos ser mais dificultoso em sua admissibilidade. A uma, a exigência constitucional é de trânsito em julgado da sentença condenatória, a qual não está subordinada à maior ou menor dificuldade na admissão de um recurso. A duas, não é impossível imaginar um STF mais generoso na admissão de repercussão geral em matéria penal, tampouco a possibilidade de aprovação de uma PEC que oponha mais obstáculos à admissão do recurso especial. ${ }^{61}$

No segundo caso, há criação judicial de uma cláusula geral segundo a qual "em crimes graves, pode-se executar a sentença precária ainda na pendência de julgamento de recurso especial”, sendo que a norma constitucional que veda o tratamento como culpado antes do trânsito em

crimes graves. Isso porque, consoante asseverei no julgamento do citado HC 126.292/SP, em que pese a presunção de não culpabilidade ser direito fundamental que impõe o ônus da prova à acusação e impede o tratamento do réu como culpado até o trânsito em julgado da sentença, ainda assim, não impõe que o réu seja tratado da mesma forma durante todo o processo. Conforme se avança e a culpa vai ficando demonstrada, a lei poderá impor tratamento de algo diferenciado. A presunção de inocência deve ser vista como um princípio relevantíssimo para a ordem jurídica ou constitucional, mas princípio suscetível de ser devidamente conformado, tendo em vista, inclusive, as circunstâncias de aplicação no caso do Direito Penal e Processual Penal. Por isso, eu entendo que, nesse contexto, não é de se considerar que a prisão, após a decisão do tribunal de apelação, haja de ser considerada violadora desse princípio. A própria credibilidade das instituições em geral, e da justiça em particular, fica abalada se o condenado por crime grave não é chamado a cumprir sua pena em tempo razoável. Em suma, a garantia da ordem pública autoriza a prisão, em casos graves, após o esgotamento das vias ordinárias. Consoante relatado, o paciente foi condenado à pena de 12 anos de reclusão, em regime inicial fechado, pela prática do delito descrito no artigo $121, \S 2^{\circ}$, inciso IV, do Código Penal, fato ocorrido em 4.9.2010, ou seja, há mais de 7 anos. A condenação restou mantida em sede de julgamento de apelação pelo Tribunal de origem, tendo rejeitado os embargos declaratórios opostos”.

${ }^{61}$ Cf. PEC 10/2017. Disponível em: <http://www25.senado.leg.br/web/atividade/materias/-/materia/128403 >. Acesso em: 07 abr. 2018 (No âmbito do Superior Tribunal de Justiça, dispõe que no recurso especial, o recorrente deverá demonstrar a relevância das questões de direito federal infraconstitucional discutidas no caso, nos termos da lei, a fim de que o Tribunal examine a admissão do recurso, somente podendo recusá-lo pela manifestação de dois terços dos membros do órgão competente para o julgamento). 
julgado nunca distinguiu entre suspeitos de crimes graves e suspeitos de crimes leves. Ademais, não havendo em nosso ordenamento um conceito legal do que sejam crimes graves (como há para crimes hediondos ou de menor potencial ofensivo), o juízo acerca do cabimento da execução provisória cairá no subjetivismo e no casuísmo, já que dependerá da convicção pessoal de cada magistrado acerca da gravidade da infração penal subjacente ${ }^{62}$. Novamente, insegurança e desigualdade.

Os dois argumentos acima vão ao encontro das considerações de "conveniência e respeito", desenvolvidas por Greco. Para usar um de seus exemplos, se proibirmos o uso da tortura com base em argumentos de conveniência - "se a tortura for permitida ainda que num único caso, ela acabará sendo usada também em outros, sendo impossível controlá-la” --, poderemos flexibilizar a proibição também por questões de conveniência: em "circunstâncias extremas" ou "graves" (atentados terroristas) ou de extrema necessidade (descoberta do cativeiro de criança sequestrada), ou quando pudermos controlar seus efeitos de contaminação (slippery slope). ${ }^{63}$ E, com isso, a "proibição forte" do art. $5^{\circ}$, III, CF, "se perde", ignorando-se que a "causa da humanidade é independente de considerações de utilidade e necessidade" e que "o mal da tortura não está em que ela não descubra a verdade ou que ela seja incontrolável, e sim na negação do torturado como ser dotado de vontade". ${ }^{64}$ No que nos diz respeito, nada impedirá tratar o não condenado como condenado (aplicando-lhe a pena sem juízo definitivo sobre sua culpa) sempre que houver um recurso "com acesso dificultado" ou quando se tratar de "crime grave", e com isso, parafraseando Greco, tornar a proibição forte do art. $5^{\circ}$, LVII, CF, e uma proibição fraca, ou contingencial.

62 Contra a criação judicial de tais cláusulas, já dizia o Min. Sepúlveda Pertence que "o regime de estrita legalidade que rege o Direito Penal não admite que, à categoria legal dos crimes hediondos, o juiz acrescente outros, segundo a sua validação subjetiva de modo a negar ao condenado o que lhe assegura a lei” (STF, RHC 80970, DJ 10/08/2001).

63 Os argumentos de conveniência estão sujeitos "aos problemas da contingência, da ponderabilidade e do ponto cego" (GRECO, Luís. Conveniência e respeito. Sobre o hipotético e o categórico na fundamentação do Direito Penal. Revista Brasileira de Ciências Criminais, v. 95, p. 43-83, 2012, p. 66).

${ }^{64}$ GRECO, Luís. Conveniência e respeito. Sobre o hipotético e o categórico na fundamentação do Direito Penal. Revista Brasileira de Ciências Criminais, v. 95, p. 43-83, 2012, p. 70. 
Por fim, parece que estamos diante de um jogo de linguagem que conduz a uma burla de "etiquetas": ${ }^{55}$ diante da inconstitucionalidade da execução da pena antes do trânsito em julgado da sentença condenatória, em lugar de assim a declarar, altera-se a categorização dessa restrição da liberdade denominando-a de prisão preventiva para a garantia da ordem pública. Assim, por meio de um erro de categorização se declara admissível o que seria inadmissível sob uma outra categorização (a correta), daí a burla. Seguindo com rigor a proposta judicial, sempre que houver sentença condenatória em crime grave na pendência de julgamento de recurso especial haverá fundamento para tal prisão preventiva, a qual, assim, de cautelar passa a ser automática, o que contraria, agora, a exigência constitucional de fundamentação cautelar para a restrição da liberdade (art. $5^{\circ}$, LXI, CF) ${ }^{66}$

Concorde-se ou não com a escolha constitucional acerca do momento a partir do qual pode ser executada a pena, o respeito à legalidade democrática é pressuposto essencial da divisão de poderes que caracteriza o Estado de Direito. Se há necessidade de revisão das normas constitucionais ou infraconstitucionais isso é tarefa que cumpre ao órgão constitucionalmente competente, o Congresso Nacional. ${ }^{67}$

\section{ConclusÃo}

Um dos caminhos para combater o instrumentalismo e a flexibilização das normas jurídicas evidenciados no "caso da execução da condenação sujeita a apelos extremos" é o de levar a sério a dogmática, cujo papel é justamente o de "definir as condições de possibilidade do direito

65 Sobre o significado dessa expressão e seu "modus operandi", cf.: GRECO, Luís. Lo vivo y lo muerto en la teoria de la pena de Feuerbach. Madrid: Marcial Pons, 2015, p. 207-208.

$\mathrm{CF}$, art. $5^{\circ}$, LXI: “ninguém será preso senão em flagrante delito ou por ordem escrita e fundamentada de autoridade judiciária competente, salvo nos casos de transgressão militar ou crime propriamente militar, definidos em lei”.

67 A abolição de direitos e garantias individuais está vedada (art. 60, § 4 ${ }^{\circ}$, IV), mas não a revisão de outras normas, como as que disciplinam recursos. Daí a via escolhida pela PEC n. 15, de 2011, também conhecida como "PEC Peluso", e que, em sua redação original, transformava os recursos extraordinário e especial em ações rescisórias. 
vigente e de orientar seu processo decisório". ${ }^{88}$ Sua função mais básica e importante é, pois, produzir segurança jurídica e igualdade na aplicação da lei, o que faz por meio do "estabelecimento de critérios para a relação entre norma e fato", com o que reduz a incerteza, estabiliza o sistema jurídico, produz coerência, controlabilidade e "reaproveitamento de soluções concretas em casos futuros". ${ }^{69}$ No desempenho dessa função, cumpre a ela oferecer as bases para que o "direito não seja aquilo que o intérprete quer que ele seja", ${ }^{70}$ nem um conjunto de "recomendações hipotéticas a serem seguidas por um príncipe prudente", ${ }^{71}$ pena de rompimento radical com a legalidade democrática, especialmente em matéria penal, onde a reserva legal também se traduz em um mandado de determinação e taxatividade (art. $5^{\circ}$, XXXIX, CF). Cumprir a lei é, portanto, reverenciar o Estado Democrático de Direito. ${ }^{72}$

\section{REFERÊNCIAS}

ALEXY, Robert. Teoria de los derechos fundamentales. Madrid: Centro de Estudios Políticos y Constitucionales, 2001.

AMARAL, Thiago Bottino do. Habeas corpus nos Tribunais Superiores: uma análise e proposta de reflexão. Rio de Janeiro: Escola de Direito do Rio de Janeiro da Fundação Getúlio Vargas, 2016.

68 REIS, Thiago. Dogmática e incerteza normativa: crítica ao substancialismo jurídico do direito civil - constitucional. Revista de Direito Civil Contemporâneo, v. 11, p. 213-238, 2017, p. 215.

69 REIS, Thiago. Dogmática e incerteza normativa: crítica ao substancialismo jurídico do direito civil - constitucional. Revista de Direito Civil Contemporâneo, v. 11, p. 213-238, 2017, p. 214-216.

70 Parafraseando: STRECK, Lenio Luiz. O que é isto - decido conforme a minha consciência? 4. ed. ele. Porto Alegre: Livraria do Advogado, 2013, p. 47.

71 GRECO, Luís. Conveniência e respeito. Sobre o hipotético e o categórico na fundamentação do Direito Penal. Revista Brasileira de Ciências Criminais, v. 95, p. 43-83, 2012, p. 71.

72 Um avanço considerável, segundo: STRECK, Lenio Luiz. O que é isto - decido conforme a minha consciência? 4. ed. ele. Porto Alegre: Livraria do Advogado, 2013, p. 171; e, ainda, em: STRECK, Lenio Luiz. Os limites semânticos e sua importância na e para a democracia. Revista da AJURIS, v. 41, n. 135, p. 173-187, 2014, p. 184. 
AMARAL, Augusto J.; CALEFFI, Paulo S. Pré-ocupação de inocência e execução provisória da pena: uma análise crítica da modificação jurisprudencial do STF. Revista Brasileira de Direito Processual Penal, v. 3, n. 3, p. 1073-1114, 2017. https:// doi.org/10.22197/rbdpp.v3i3.102

AMARAL, Marianne G.; SUXBERGER, Antonio H. A execução provisória da pena e sua compatibilidade com a presunção de inocência como decorrência do sistema acusatório. Revista de Direito Brasileira, v. 16, n. 7, p. 186-210, 2017. https://doi. org/10.5585/rdb.v16i7.500

ÁVILA, Humberto. Teoria dos princípios: da definição à aplicação dos princípios jurídicos. 5. ed. São Paulo: Malheiros, 2006.

BADARÓ, Gustavo Henrique. Processo penal. 3. ed. São Paulo: Revista dos Tribunais, 2015.

BADARÓ, Gustavo Henrique; LOPES JÚNIOR, Aury. Presunção de inocência: do conceito de trânsito em julgado da sentença penal condenatória. 2016. Disponível em: <http://www.emporiododireito.com.br/wp-content/uploads/2016/06/ Parecer_Presuncao_de_Inocencia_Do_concei.pdf $>$ Acesso em: 20 fev. 2018.

BARROSO, Luís Roberto; SCHIETTI, Rogério. Execução penal, opinião e fatos. Folha de São Paulo, 02/02/2018. Disponível em: <https://www1.folha.uol.com. br/opiniao/2018/02/luis-roberto-barroso-e-rogerio-schietti-execucao-penal-opiniao-e-fatos.shtml>. Acesso em: 20 fev. 2018.

CARVALHO, Salo de; WUNDERLICH, Alexandre. Crítica à execução antecipada da pena: a revisão da Súmula 367 pelo STJ. In: Crítica à execução penal. 2. ed. Rio de Janeiro: Lumen Juris, 2007, p. 447-462.

GRECO, Luís. Conveniência e respeito. Sobre o hipotético e o categórico na fundamentação do Direito Penal. Revista Brasileira de Ciências Criminais, v. 95, p. 43-83, 2012.

GRECO, Luís. Lo vivo y lo muerto en la teoria de la pena de Feuerbach. Madrid: Marcial Pons, 2015.

LEITE, Alaor. Domínio do fato, domínio da organização e responsabilidade penal por fatos de terceiros. Os conceitos de autor e partícipe na AP 470 do Supremo Tribunal Federal. In: GRECO, Luís [et al.]. Autoria como domínio do fato: estudos introdutórios sobre o concurso de pessoas no direito penal brasileiro. São Paulo: Marcial Pons, 2014, p. 123-168.

LOPES JÚNIOR, Aury. Direito processual penal. 10. ed. São Paulo: Saraiva, 2013.

MORAES, Maurício Zanóide de. Presunção de inocência no processo penal brasileiro: análise de sua estrutura normativa para a elaboração legislativa e para a decisão judicial. Rio de Janeiro: Lumen Juris, 2010. 
NEUMANN, Ulfrid. Bedingungen der Validität des naturalistischen Fehlschlusses. In: Festschrift für Matthias Mahlmann. Baden-Baden: Nomos, 2011, p. 62-70.

QUEIROZ, Rafael M. R. A presunção de inocência libertada. Jota, 2018. Disponível em: <https://www.jota.info/opiniao-e-analise/artigos/presuncao-de-inocencia-libertada-28022018>. Acesso em 28 mar. 2018.

REIS, Thiago. Dogmática e incerteza normativa: crítica ao substancialismo jurídico do direito civil - constitucional. Revista de Direito Civil Contemporâneo, v. 11, p. 213-238, 2017.

SCHIETTI, Rogério; BARROSO, Luís Roberto. Execução penal, opinião e fatos. Folha de São Paulo, 2018. Disponível em: <https://www1.folha.uol.com.br/ opiniao/2018/02/luis-roberto-barroso-e-rogerio-schietti-execucao-penal-opiniao-e-fatos.shtml?loggedpaywall>. Acesso em: 02 mar. 2018.

SILVA, Virgílio Afonso da. O proporcional e o razoável. Revista dos Tribunais, v. 798, p. 23-50, 2002.

STRECK, Lenio Luiz. O que é isto - decido conforme a minha consciência? 4. ed. ele. Porto Alegre: Livraria do Advogado, 2013.

STRECK, Lenio Luiz. Os limites semânticos e sua importância na e para a democracia. Revista da AJURIS, v. 41, n. 135, p. 173-187, 2014.

SUXBERGER, Antonio H.; AMARAL, Marianne G. A execução provisória da pena e sua compatibilidade com a presunção de inocência como decorrência do sistema acusatório. Revista de Direito Brasileira, v. 16, n. 7, p. 186-210, 2017. https://doi. org/10.5585/rdb.v16i7.500

\section{Informações adicionais e declarações dos autores (integridade científica)}

Agradecimentos (acknowledgement): Meus agradecimentos a meus exigentes revisores Luís Greco, Adriano Teixeira, Alaor Leite, Frederico Horta, Mariana Tosi e Ronan Rocha.

Declaração de conflito de interesses (conflict of interest declaration): a autora confirma que não há conflitos de interesse na realização das pesquisas expostas e na redação deste artigo.

Declaração de autoria e especificação das contribuições (declaration of authorship): todas e somente as pessoas que atendem os requisitos de autoria deste artigo estão listadas como autores. 
Declaração de ineditismo e originalidade (declaration of originality): a autora assegura que o texto aqui publicado não foi publicado anteriormente em outro meio e que futura republicação somente se realizará com a indicação expressa da referência desta publicação original; também atesta que não há plágio de terceiros ou autoplágio. Trata-se de versão ampliada de fala apresentada no IV Colóquio sobre o Supremo Tribunal Federal, em 4 de dezembro de 2017, promovido pelo Instituto Victor Nunes Leal e pela AASP. Naquela ocasião, pretendi homenagear o Min. Sepúlveda Pertence, ali presente, o que explica as referências preferenciais a precedentes de sua lavra e, ainda, a linguagem direta e tendencialmente informal empregada no texto.

\section{Dados do processo editorial}

(http://www.ibraspp.com.br/revista/index.php/RBDPP/about/editorialPolicies)

- Recebido em: 02/03/2018

Equipe editorial envolvida

- Controle preliminar e verificação de plágio: 02/03/2018

- Avaliação 1: 07/03/2018

- Avaliação 2: 20/03/2018

- Avaliação 3: 20/03/2018

- Editor-chefe: 1 (VGV)

- Editor-assistente: 1 (TACJ)

- Revisores: 4

- Avaliação 4: 27/03/2018

- Decisão editorial preliminar: 06/04/2018

- Retorno rodada de correções 1: 18/04/2018

- Decisão editorial final: 23/04/2018

\section{COMO CITAR ESTE ARTIGO:}

ESTELLITA, Heloisa. A flexibilização da legalidade no Supremo Tribunal Federal: o caso da execução da condenação sujeita a apelos extremos. Revista Brasileira de Direito Processual Penal, Porto Alegre, vol. 4, n. 2, p. 709-730, mai./ago. 2018. https://doi.org/10.22197/rbdpp.v4i2.141

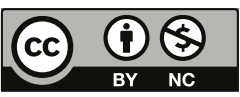

Esta obra está licenciada com uma Licença Creative Commons Atribuição-NãoComercial 4.0 Internacional. 